\title{
TFG wt Allele
}

National Cancer Institute

\section{Source}

National Cancer Institute. TFG wt Allele. NCI Thesaurus. Code C97835.

Human TFG wild-type allele is located in the vicinity of 3q12.2 and is approximately $40 \mathrm{~kb}$ in length. This allele, which encodes protein TFG, plays a role in the modulation of signaling. A chromosomal translocation $\mathrm{t}(2 ; 3)(\mathrm{p} 23 ; \mathrm{q} 21)$ of this gene and the ALK gene is associated with anaplastic large cell lymphoma. A second translocation $t(1 ; 3)(q 21 ; q 11)$ of this gene and the NTRK1 gene is associated with thyroid papillary carcinoma. A third translocation of this gene and the NR4A3 gene is associated with extraskeletal myxoid chondrosarcoma. 